\title{
Steroid Minimization in Adults with Minimal Change Disease
}

\author{
Abbal Koirala J. Ashley Jefferson \\ Division of Nephrology, University of Washington, Seattle, WA, USA
}

\begin{abstract}
Keywords
Glomerular disease - Minimal change disease .

Glucocorticoids · Nephrotic syndrome .

Immunosuppression · Tacrolimus · Rituximab .

Mycophenolate
\end{abstract}

\begin{abstract}
Background: Minimal change disease (MCD) causes approximately $10 \%$ of nephrotic syndrome in adults. While glucocorticoids (GCs) effectively induce remission in MCD, the disease has a high relapse rate (50-75\%), and repeated exposure to GCs is often required. The adverse effects of GCs are well recognized and commonly encountered with the high doses and recurrent courses used in MCD. Summary: In this review, we will discuss the standard therapy of MCD in adults and then describe new therapeutic options in induction therapy and treatment of relapses in MCD, minimizing the exposure to GCs. Key Messages: Steroid minimization strategies may decrease adverse effects in the treatment of MCD.

(c) 2021 The Author(s)

Published by S. Karger AG, Basel
\end{abstract}

\section{Introduction}

Minimal change disease (MCD) is the commonest cause of nephrotic syndrome (NS) in children and accounts for $\sim 10 \%$ of NS in adults [1-3]. Corticosteroids have long been the backbone of treatment for many forms of glomerular disease and are usually very effective in MCD. Most adults and children with MCD respond

karger@karger.com www.karger.com/gdz

Karger"
(C) 2021 The Author(s)

Published by S. Karger AG, Basel

This is an Open Access article licensed under the Creative Common Attribution-NonCommercial-4.0 International License (CC BY-NC) (http://www.karger.com/Services/OpenAccessLicense), applicable to the online version of the article only. Usage and distribution for commercial purposes requires written permission. briskly to treatment with high-dose prednisone or prednisolone, but high-dose glucocorticoids (GCs), and in particular, recurrent courses of GC, are associated with a wide range of serious side effects. The adverse consequences of high-dose GC are increasingly recognized, and multiple recent studies in a range of glomerular diseases are now using much lower doses of GC [4-8]. Emerging data in MCD now suggest alternative therapies to GC which may have more favorable side effect profiles.

\section{Proposed Mechanism of Action for GCs in MCD}

MCD is primarily a disorder of the podocyte (podocytopathy) as illustrated by the diffuse foot process effacement seen on electron microscopy, however, the underlying pathophysiology remains unclear. In the absence of clearly deposited immunoglobulin or complement in kidney biopsies, prior studies have focused on the role of $\mathrm{T}$ cell dysfunction (reviewed by Saleem and Kobayashi [9]). Abnormalities in T-regulatory cells, which attenuate immune responses by suppressing T-effector cells, have been described [10]. Upregulation of CD80, a transmembrane protein present on antigen-presenting cells that acts as a costimulatory signal for $\mathrm{T}$ cell activation, has been noted, and increased urinary CD80 levels have been proposed as a biomarker for active MCD [11]. Interleukin-13 produced by Th2 T cells has been shown to cause podocyte injury in an animal model of MCD [12]. By contrast, recent studies have demonstrated beneficial effects of rituximab in the treatment of MCD, suggesting a role
Correspondence to:

J. Ashley Jefferson, jashleyj@uw.edu 
Table 1. Clinical features of MCD at the time of kidney biopsy in 4 large retrospective case series

\begin{tabular}{|c|c|c|c|c|}
\hline & Szeto et al. [27] & Fenton et al. [28] & Waldman et al. [26] & Maas et al. [29] \\
\hline Series & $n=340$, China & $n=78, \mathrm{UK}$ & $n=95$, New York & $n=125$, The Netherlands \\
\hline Age, years & 38 & 36 & 45 & 46 \\
\hline Sex (female), $\%$ & 44 & 40 & 61 & 58 \\
\hline Microhematuria, \% & 23 & 15 & 29 & $*$ \\
\hline Proteinuria, g/day & 4.9 & 5 & 9.9 & 9.6 \\
\hline Hypertension, \% & 21 & * & 43 & 37 \\
\hline
\end{tabular}

MCD, minimal change disease. * Data not available.

for B cells in MCD [13]. Alterations in immunoglobulin subclasses have been described in NS, and plasma soluble CD23, a classic B cell activation marker, is increased in the relapse of NS [14]. Nephrin distribution in the podocyte foot processes is altered in MCD [15]. Anti-nephrin antibodies produce an MCD-like lesion in animal models [16], and have been proposed to play a role in human MCD [17].

GC exert anti-inflammatory and immunosuppressive effects by both genomic and nongenomic pathways. GC and their cytoplasmic receptors form a complex that enters the nucleus and binds to specific GC response elements within genes [18]. This increases the expression of anti-inflammatory proteins (transactivation) or decreases the production of pro-inflammatory proteins (transrepression) [18]. Many of the adverse effects of GC are induced by transactivation, whereas the beneficial anti-inflammatory effects are mainly due to transrepression [18]. Much of GC immunosuppressive properties are through nongenomic effects mediated by membrane GC receptors, partly through inhibition of the NF-kB transcription factor pathway in lymphocytes $[18,19]$.

It has long been assumed that the beneficial effects of GC in MCD are related to these immunosuppressive effects, however, GC may have direct protective effects on podocytes. Experimental studies suggest that corticosteroids may protect podocytes from injury. Cultured podocytes express the key components of the GC receptor complex, including heat shock protein 90 and the immunophilins FKBP51 and FKBP52 [20]. In human cultured podocytes, dexamethasone treatment for $24 \mathrm{~h}$ increased the phosphorylation of nephrin and stabilized the podocyte actin cytoskeleton [21]. Prednisone reduced podocyte apoptosis and increased the number of podocyte progenitors in a murine model of FSGS [22]. Dexameth- asone pretreated murine podocytes stimulated with Ang II prevented podocyte motility and actin disassembly via modulation of cGMP production [23].

\section{Traditional GC Treatment of MCD in Adults}

The traditional therapy of MCD is induction with high-dose GC (prednisone or prednisolone). GC therapy has been well studied in several large prospective randomized trials in children and observational studies in adults (Tables 1 and 2 provide data from the four largest retrospective series in adults).

In the only randomized controlled trial with prednisone in adults with MCD published in 1970, 31 adult patients with MCD were treated with low-dose prednisone ( $<30 \mathrm{mg}$ daily) versus nonspecific therapy as control [24]. More than $75 \%$ of low-dose prednisone-treated patients had remission of proteinuria to $<1 \mathrm{~g} /$ day within 6 months. By comparison, $50 \%$ of those in the untreated group were in remission at 18 months and approximately $70 \%$ at 3 years. Of note, $5-10 \%$ of the patients spontaneously remitted within 3 months in the untreated group.

A traditional steroid regimen for MCD in adult patients is oral prednisone $1 \mathrm{mg} / \mathrm{kg}$ (up to $80 \mathrm{mg}$ /day) or 2 $\mathrm{mg} / \mathrm{kg}$ on alternate days (up to $120 \mathrm{mg} /$ day) for a minimum of 4 weeks and a maximum of 16 weeks (as tolerated). After remission, GC is tapered over at least 24 weeks.

\section{Efficacy of GCs in the Treatment of MCD}

More than $85 \%$ of children attain remission after 8 weeks of steroid therapy compared to about $70 \%$ of adults (aged 15-39 years), but only $30 \%$ of adults aged 
Table 2. Response to glucocorticoid therapy in MCD in 4 large retrospective case series

\begin{tabular}{|c|c|c|c|c|}
\hline Series & $n=340$, China & $n=78, \mathrm{UK}$ & $n=95$, New York & $n=125$, The Netherlands \\
\hline Time to remission (median) & 10 weeks & 5 weeks ( $2-11$ weeks) & 13 weeks & $\begin{array}{l}68 \% \text { ( } 8 \text { weeks }) \\
88 \% \text { ( } 16 \text { weeks })\end{array}$ \\
\hline Steroid resistant, \% & 10 & 10 & 27 & 10 \\
\hline Relapse rate, $\%$ & 38 & 61 & 73 & 54 \\
\hline Median time to relapse & $*$ & 11 months & 22 weeks & 9 months \\
\hline \multirow{2}{*}{ Complications, $\%$} & Major infection (5) & Infection (14) & Infection (7) & Infection (12) \\
\hline & $\mathrm{DM}(18)$ & $\mathrm{DM}(12)$ & $\mathrm{DM}(1)$ & $\mathrm{DM}(7)$ \\
\hline Median follow-up & 175 months (120-235 months) & 72 months (6-190 months) & 139 weeks $(119-420)$ & 59 months (4-308) \\
\hline
\end{tabular}

MCD, minimal change disease. ${ }^{*}$ Data not available.

Table 3. Adverse effects of corticosteroids [39]

\begin{tabular}{ll}
\hline System & Adverse effects \\
\hline $\begin{array}{l}\text { Musculoskeletal } \\
\text { Endocrine and metabolic }\end{array}$ & $\begin{array}{l}\text { Osteoporosis, avascular necrosis, myopathy } \\
\text { Glucose intolerance and diabetes, fat redistribution and obesity, suppression of sex } \\
\text { hormone secretion }\end{array}$ \\
Cardiovascular & $\begin{array}{l}\text { Dyslipidemia, premature atherosclerosis and cardiovascular disease, sodium retention } \\
\text { and hypertension, edema }\end{array}$ \\
Dermatological & Cutaneous atrophy, acne, hirsutism, alopecia \\
Ophthalmological & Cataract, glaucoma \\
Gastrointestinal & $\begin{array}{l}\text { Peptic ulcer disease, gastritis, gastrointestinal bleeding, pancreatitis } \\
\text { Infectious }\end{array}$ \\
Vsychological and behavioral disturbances & Steroid psychosis, mood disturbances \\
\hline
\end{tabular}

40-78 years achieve remission with 8 weeks of steroid treatment. With more prolonged treatment (up to 24 weeks), $90 \%$ of adults with MCD will achieve a complete remission (CR), but at the expense of markedly increased GC exposure [25]. Even though MCD is usually steroid-responsive, relapse of NS following discontinuation of initial steroid therapy is very common. The relapse rate in adults is $50-75 \%$ [26-29], and about $30 \%$ of adults will develop frequent relapses ( $\geq 2$ relapses in 6 months or $\geq 4$ relapses in 1 year) or become steroiddependent (relapse during steroid taper or 15 days after GC discontinuation) $[25,26,30]$ (Table 2). Occasional, infrequent relapses in GC responsive patients are usually treated with a short course of prednisone. Continuous low-dose alternate-day prednisone may sustain remission in some steroid-dependent and frequently relapsing MCD, but often results in a high cumulative GC exposure over time.

Steroid Minimization in Adults with Minimal Change Disease

\section{Adverse Effects of GC Treatment in MCD}

Despite the many beneficial effects, long-term GC exposure is associated with multiple adverse effects, including infection, bone disease, dysglycemia, obesity, hypertension, psychosis, gastrointestinal bleeding, cataracts, and long-term risks of cardiovascular disease (Table 3) [27, 31-36]. The response to induction therapy in adults with GC is often delayed compared to children, and longer courses of GC are commonly prescribed [25, 26]. As MCD often follows a relapsing course, patients are exposed to repeated doses of corticosteroids which increases the long-term cumulative GC exposure [37-40].

Infection risk: Although proteinuria is more selective in MCD compared to other glomerular diseases such as FSGS or membranous nephropathy, loss of immunoglobulin and complement proteins in the urine of 


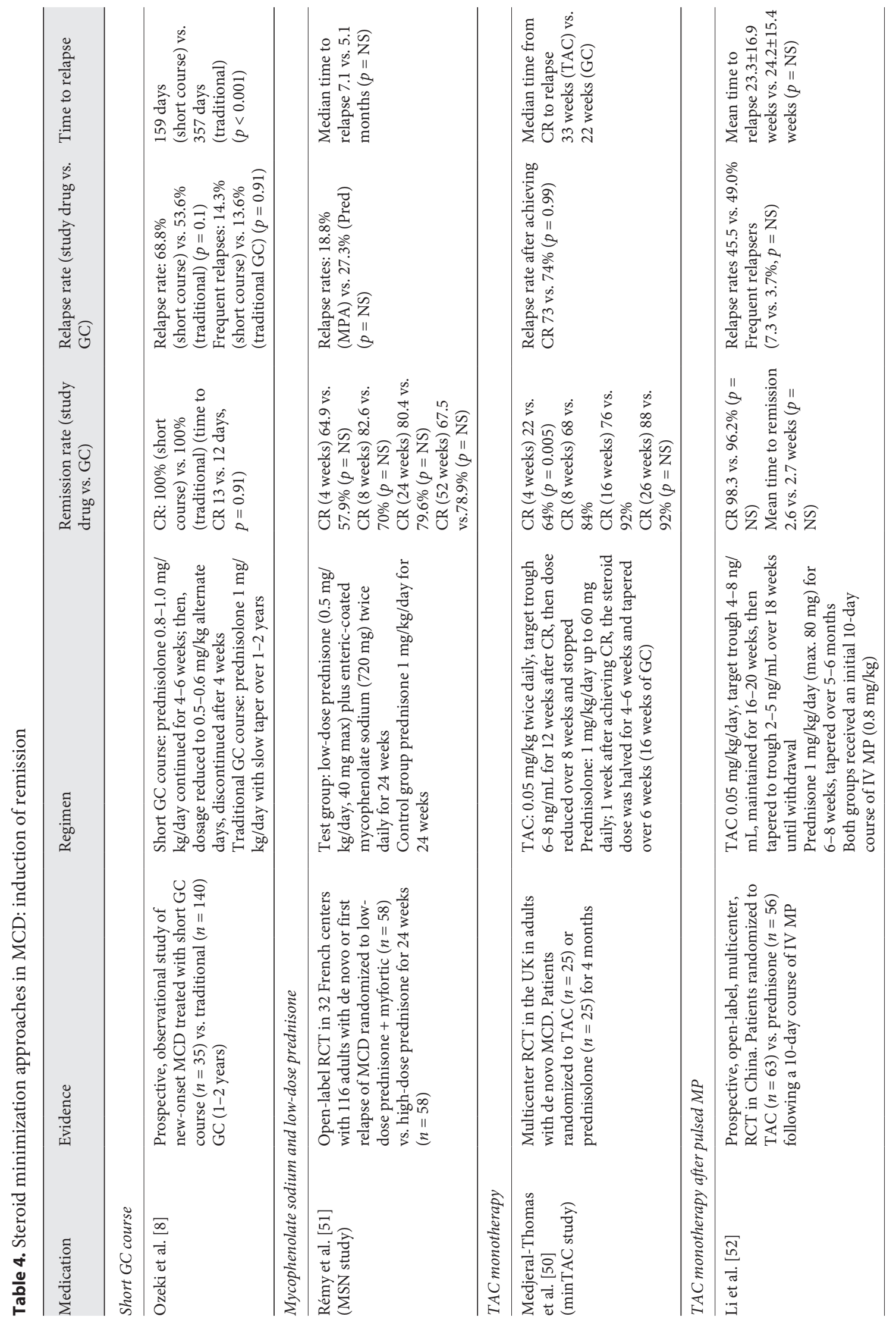




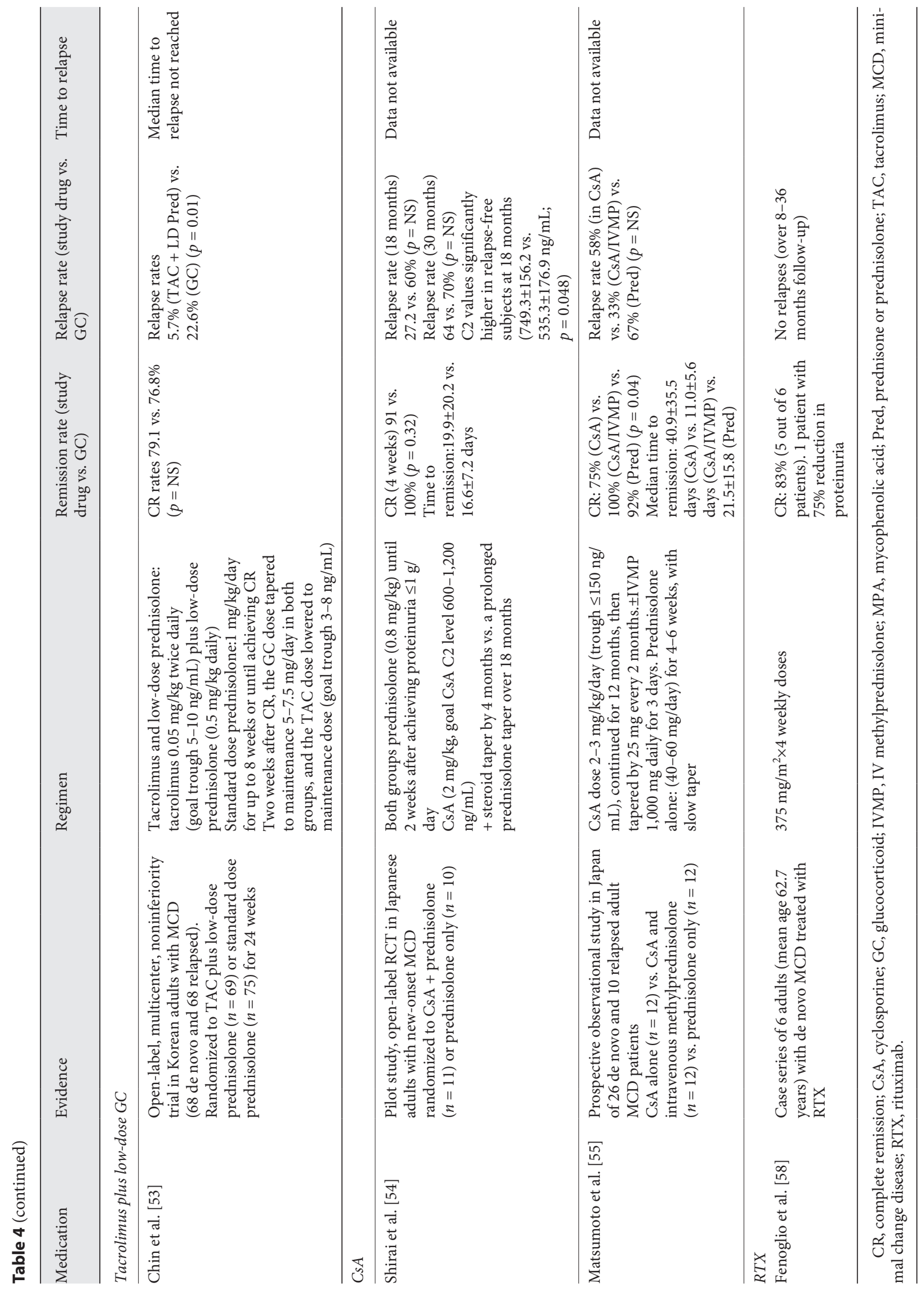


nephrotic patients and depressed $\mathrm{T}$ cell function make patients more prone to infection [41]. Most observational studies cite the incidence of infectious complications in MCD from 5 to 15\% [26-29]. GC therapy is a major contributor to this infection risk and cumulative GC exposure from multiple relapses increases this risk. Szeto et al. [27] noted a higher incidence of infectious complications in steroid-resistant NS (15\%) and frequent relapsers (6\%) than nonrelapsing MCD $(2.8 \%, p$ $=0.03)$, although it is unclear how much is due to the disease itself versus the GC treatment. Notably, Waldman et al. [26] did not find any difference in complications in MCD patients between those treated with daily versus alternate-day steroids. Glenn et al. [42] prospectively followed subjects in the Cure Glomerulonephropathy Network (CureGN) study and found infection-related acute care events were more common among patients with GC exposure versus those without GC exposure at enrollment (50.6 vs. 28.6 infection/100 person-years). Other risk factors for infection included younger age, hypoalbuminemia, and nephrotic range proteinuria.

Musculoskeletal complications: Many of the musculoskeletal adverse effects are likely to occur with recurrent exposure to GC. The incidence of bone avascular necrosis and fracture was higher in frequently relapsing MCD patients than infrequent relapsers (4 vs. $1.1 \%$ for AVN, $p=\mathrm{NS}$ and 15 vs. $5 \%$ for any fracture, $p=0.006$ ) [27]. Kyrieleis et al. [36] examined long-term adverse outcomes of frequently relapsing childhood-onset MCD patients who continued to relapse after puberty. These patients frequently developed complications such as hypertension (47\%), cataracts (20\%), and lumbar spine osteoporosis (33\%). Hegarty et al. [43] studied 34 adult survivors of childhood MCD and they were found to have a significant reduction in forearm trabecular bone mineral density $(Z$ score -0.95 and $T$ score $-1.04, p<0.0001)$, placing them at increased fracture risk at this site; these adults also had short stature (height $Z$ score $-0.45, p=0.007$ ) and higher BMI (BMI $Z$ score $1.62, p<0.0001)$ than their age-matched counterparts.

To protect against some of the infectious complications of GC, adults with NS should be vaccinated against encapsulated bacteria such as Pneumococcus per CDC guidelines [44]. Live vaccines should be avoided during and within 4 weeks prior to starting immunosuppression. Prophylaxis against Pneumocystis jirovecii pneumonia should be considered if exposed to high-dose GC ( $\geq 20 \mathrm{mg}$ of prednisone) for $\geq 4$ weeks $[45,46]$.

\section{Steroid Minimization Approaches: Induction of Remission}

Given the clear concerns regarding the adverse effects of high-dose GC, several approaches to limit the GC dose have been studied, both during the induction phase in achieving remission (Table 4) and in preventing further relapses.

\section{Shorter GC Taper after Induction}

After successful induction therapy with high-dose GCs, which occurs in $90 \%$ of adults, GC tapering has usually been slow (over 3-6 months) in adults to reduce disease relapse frequency. By contrast, in children, three recent randomized trials demonstrated that a shorter taper (over 4-8 weeks) was safe, did not lead to an increased relapse rate, and is now the standard of care in pediatric MCD [47-49].

In adults, the data are more limited. Ozeki et al. [8] reported a prospective, observational study to evaluate the effectiveness of a 2-month taper in adult steroid-sensitive MCD. In this study, 35 patients with new-onset NS from MCD were initiated on prednisolone at an initial dose of $0.8-1.0 \mathrm{mg} / \mathrm{kg} /$ day and continued for $4-6$ weeks. The dosage was then reduced to $0.5-0.6 \mathrm{mg} / \mathrm{kg}$ alternate days and discontinued after 4 weeks. This short-term steroid group was compared to a historical cohort of 140 adult MCD patients treated with a more extended duration steroid regimen. The relapse rate was not statistically greater in this short-term group versus historical controls (68.8 vs. $53.6 \%, p=0.1$ ), and there was no difference in frequent relapsers ( 14.3 vs. $13.6 \%, p=0.91$ ). Overall, patients treated with the short-term steroid regimen received about half the cumulative dose of prednisolone than patients treated with the conventional regimen (4,199 mg of prednisolone over 24 months of follow-up compared to 8,540 $\mathrm{mg}$ of prednisolone over the same period). Despite having a substantial discrepancy in corticosteroid exposure, there were no clear differences in reported adverse events.

With the intention of lowering GC exposure, some adults with MCD now receive a regimen consisting of an initial dose (prednisone 1 or $2 \mathrm{mg} / \mathrm{kg} /$ every other day) until 1 week after CR, then the dose is halved for $4-6$ weeks, then tapered off over a further 6 weeks, ensuring patients receive a minimum of 16 weeks treatment [50].

\section{Mycophenolate Sodium with Low-Dose Prednisone}

Rémy et al. [51] conducted an open-label randomized controlled trial (MSN study) involving 32 French centers with 116 adults with de novo or first relapse of MCD. Par- 
ticipants randomly assigned to the test group $(n=58)$ received low-dose prednisone $(0.5 \mathrm{mg} / \mathrm{kg} /$ day, maximum $40 \mathrm{mg} /$ day) plus enteric-coated mycophenolate sodium (720 mg twice daily for 24 weeks) versus the control group $(n=58)$ who received conventional high-dose prednisone (1 mg/kg/day, maximum $80 \mathrm{mg} /$ day) tapered over 24 weeks. Baseline characteristics included a mean age of 44 years, normal renal function (eGFR $87 \mathrm{~mL} / \mathrm{min}$ ), proteinuria $(7.9 \mathrm{~g} / \mathrm{g})$, and serum albumin $1.6 \mathrm{~g} / \mathrm{dL}$.

After 4 weeks of treatment, there was no significant difference between the two groups in the CR rate (64.9 vs. $57.9 \%, p=0.44)$. Secondary outcomes, including CR after 8,24 , and 52 weeks of treatment, also did not differ between the two groups ( 82.6 vs. $70 \%$ at 8 weeks; 80.4 vs. $79.6 \%$ at 24 weeks; 67.5 vs. $78.9 \%$ at 52 weeks). During 52 weeks of follow-up, relapse rates in both groups were remarkably low (18.75 vs. $27.3 \%)$. Serious adverse effects did not differ between the groups.

\section{Tacrolimus Monotherapy}

Medjeral-Thomas et al. [50] studied 50 adults with de novo MCD in a multicenter, prospective, open-label trial involving six nephrology units across the UK randomized to tacrolimus $(0.05 \mathrm{mg} / \mathrm{kg}$ twice daily, target trough 6-8 $\mathrm{ng} / \mathrm{mL}, n=25)$ or prednisolone ( $1 \mathrm{mg} / \mathrm{kg}$ daily up to 60 $\mathrm{mg}$ daily, $n=25)$. Twelve weeks after achieving CR, the tacrolimus dose was gradually reduced over 8 weeks and stopped. In the prednisolone group, 1 week after achieving CR, the steroid dose was halved for 4-6 weeks, then gradually reduced and stopped over a further 6 weeks, ensuring patients received a minimum of 16 weeks of prednisolone. The patients' median age was 43 years, and renal function was preserved (mean serum creatinine $0.82 \mathrm{mg} / \mathrm{dL}$ ) with heavy proteinuria (urine protein creatinine ratio $7.3 \mathrm{~g} / \mathrm{g}$ ) and serum albumin $1.6 \mathrm{~g} / \mathrm{dL}$.

There were no significant differences between the prednisolone and tacrolimus treatment groups in CR rates at 8 weeks ( 84 vs. $68 \%$ ), 16 weeks ( 92 vs. $76 \%$ ), or 26 weeks (92 vs. $88 \%$ ), but post hoc analysis demonstrated that a higher proportion of patients treated with prednisolone attained CR at 4 weeks (64 vs. 22\%, $p=0.005$ ). Relapse rates after achieving CR were high in both groups ( 74 vs. $73 \%, p=$ 0.99 ), mostly occurring after immunosuppression had been discontinued. Although there were small numbers in this study, tacrolimus monotherapy may be a good option for some patients, although prednisolone resulted in a higher remission rate at earlier time points (4 weeks) and may be preferred in patients with severe NS.

Li et al. [52] conducted a prospective, open-label, multicenter, randomized, controlled trial in eight renal units across China. Patients were randomized to receive oral prednisone $(n=56)$ or tacrolimus $(n=63)$ after a 10 -day course of intravenous methylprednisolone $(0.8$ $\mathrm{mg} / \mathrm{kg}$ per day) in both groups. The initial prednisone dose was $1 \mathrm{mg} / \mathrm{kg}$ per day (maximum $80 \mathrm{mg}$ /day) for 6-8 weeks, then tapered over a further 5-6 months. Tacrolimus was initiated at $0.05 \mathrm{mg} / \mathrm{kg}$ per day and adjusted to a target trough whole-blood level of 4-8 ng/ $\mathrm{mL}$ and maintained for 16-20 weeks, then tapered to a trough level of $2-5 \mathrm{ng} / \mathrm{mL}$ over 18 weeks until complete withdrawal. The treatment course for both groups was 36 weeks. Remission rates were high in both groups ( 96.2 vs. $98.3 \%)$, and the mean time to remission (2.7 \pm 2.3 vs. $2.6 \pm 2.6$ weeks) was similar between GC-treated and tacrolimus-treated patients. Relapse rates ( 49.0 vs. $45.5 \%)$ and mean time to relapse (24.2 \pm 15.4 ; vs. $23.3 \pm$ 16.9) were similar between the two groups. Adverse events occurred more frequently in the GC group (128 vs. 81 in the tacrolimus group). It should be highlighted that pulse intravenous methylprednisolone treatment was given for 10 days at the beginning of this study in both treatment arms.

\section{Tacrolimus with Low-Dose Corticosteroids}

Chin et al. [53] conducted a 24-week, open-label, multicenter, noninferiority trial in 144 Korean adults with MCD (68 de novo and 68 relapsed MCD). They were randomized to receive tacrolimus $(0.05 \mathrm{mg} / \mathrm{kg}$ twice daily, goal trough 5-10 ng/mL) plus low-dose prednisolone (0.5 $\mathrm{mg} / \mathrm{kg}$ daily), or standard dose prednisolone $(1 \mathrm{mg} / \mathrm{kg})$, for up to 8 weeks or until achieving CR. Two weeks after $\mathrm{CR}$, the steroid dose was tapered to a maintenance dose of $5-7.5 \mathrm{mg} /$ day in both groups, and the tacrolimus dose was lowered to the maintenance dose (goal trough 3-8 $\mathrm{ng} / \mathrm{mL}$ ) until 24 weeks after study drug initiation. CR rates were similar in both groups (79.1 vs. $76.8 \%)$ with no difference in time to remission. The relapse rate at 24 weeks was lower in the maintenance tacrolimus plus tapered steroid group (5.7 vs. $22.6 \%, p=0.01$ ).

\section{Cyclosporine Induction}

There have been few studies on cyclosporine (CsA) monotherapy in adult MCD. Shirai et al. [54] conducted a pilot open-label RCT in Japanese adults $(n=21)$ with new-onset MCD. Adult new-onset MCD patients were initially treated with prednisolone $(0.8 \mathrm{mg} / \mathrm{kg})$ and 2 weeks after achieving proteinuria $\leq 1 \mathrm{~g} /$ day were randomized to CsA (2 mg/kg, goal CsA C2 level 600-1,200 ng/ $\mathrm{mL}$ ) with steroid taper by 4 months versus a prolonged prednisolone taper over 18 months. After 30 months, fol- 
Table 5. Steroid minimization approaches in MCD: treatment of relapsing disease

\begin{tabular}{|c|c|c|c|c|}
\hline Medication & Evidence & Regimen & Relapse rate & Time to relapse \\
\hline \multicolumn{5}{|l|}{$C Y C$} \\
\hline Waldman et al. [26] & $\begin{array}{l}\text { Retrospective case series }(n=20) \text { as } 2 \text { nd line } \\
\text { agent. Five patients received concurrent GC } \\
\text { at the initiation of CYC }\end{array}$ & $\begin{array}{l}100-150 \mathrm{mg} \text { (mean dose } \\
124 \mathrm{mg} / \text { day) for } 12 \text { weeks }\end{array}$ & $35 \%$ relapse rate & $\begin{array}{l}\text { Mean time: } 18 \\
\text { months }(6-42)\end{array}$ \\
\hline Fenton et al. [28] & $\begin{array}{l}\text { Retrospective observational study in the UK. } \\
\text { Oral CYC used in } 10 \text { patients ( } 2 \text { SR and } 8 \mathrm{FR} \text { ) } \\
\text { as } 2 \text { nd line agent for } 9 \text { weeks }\end{array}$ & Data not available & $60 \%$ relapse rate & $\begin{array}{l}\text { Median time: } \\
20 \text { months }(5- \\
44)\end{array}$ \\
\hline Maas et al. [29] & $\begin{array}{l}\text { Retrospective cohort study. Fourteen patients } \\
\text { treated with CYC as } 2 \text { nd line with GC. GC } \\
\text { dose was tapered over time. Seven patients } \\
\text { received } 2 \text { courses of CYC }\end{array}$ & $\begin{array}{l}150 \mathrm{mg}(100-200 \mathrm{mg}) \text { daily } \\
\text { for } 13 \text { weeks }\end{array}$ & $64 \%$ relapse rate & $\begin{array}{l}\text { Data not } \\
\text { available }\end{array}$ \\
\hline Nolasco et al. [30] & $\begin{array}{l}\text { Retrospective case series }(n=36) \text { in relapsing } \\
\text { MCD ( } 2 \text { patients as initial therapy). Eleven } \\
\text { patients received concurrent GC at the start of } \\
\text { treatment and } 25 \text { received CYC alone }\end{array}$ & $\begin{array}{l}2-2.5 \mathrm{mg} / \mathrm{kg} / \mathrm{day} \text { for } 8-14 \\
\text { weeks }\end{array}$ & $\begin{array}{l}41 \% \text { relapse rate } \\
\text { Follow-up duration } 5 \text { years }\end{array}$ & $\begin{array}{l}\text { Data not } \\
\text { available }\end{array}$ \\
\hline Mak et al. [59] & $\begin{array}{l}\text { Retrospective cohort study in FR/SD patients } \\
(n=22) . \text { Second course of CYC was given in } \\
6 \text { relapsers }\end{array}$ & $2-2.5 \mathrm{mg} / \mathrm{kg}$ for 8 weeks & $\begin{array}{l}56 \% \text { relapse rate in SD patients } \\
20 \% \text { relapse rate in FR patients }\end{array}$ & $\begin{array}{l}\text { Mean time to } \\
\text { relapse } 18 \\
\text { months }(6-27)\end{array}$ \\
\hline Ponticelli et al. [60] & $\begin{array}{l}\text { Open-label RCT in } 73 \text { patients with SD or FR } \\
\text { MCD (CYC vs. CsA) }\end{array}$ & $2.5 \mathrm{mg} / \mathrm{kg} /$ day for 8 weeks & $\begin{array}{l}33 \% \text { relapse rate in } \mathrm{FR} \text { and } \\
40 \% \text { relapse rate in SD patients } \\
37 \% \text { relapse rate at } 24 \text { months } \\
(60 \% \text { adults and } 32 \% \text { children })\end{array}$ & $\begin{array}{l}\text { Data not } \\
\text { available }\end{array}$ \\
\hline Li et al. [61] & $\begin{array}{l}\text { Prospective cohort study in SD MCD. } \\
\text { Thirteen patients received CYC and } 11 \\
\text { patients received TAC along with prednisone } \\
\text { ( } 0.5 \mathrm{mg} / \mathrm{kg} / \text { day), which was tapered off } \\
\text { throughout the study }\end{array}$ & $\begin{array}{l}750 \mathrm{mg} / \mathrm{m}^{2} / \mathrm{month} \mathrm{IV} \text { for } \\
6 \text { months }\end{array}$ & $\begin{array}{l}40 \% \text { relapse rate in the CYC group } \\
\text { Follow-up duration } 12-46 \text { months }\end{array}$ & $\begin{array}{l}\text { Data not } \\
\text { available }\end{array}$ \\
\hline \multicolumn{5}{|l|}{ CsA } \\
\hline Waldman et al. [26] & $\begin{array}{l}\text { Retrospective case series }(n=39) \text { as } 2 \text { nd line } \\
\text { agent. Twelve patients received concurrent } \\
\text { GC at the beginning }\end{array}$ & $\begin{array}{l}220 \mathrm{mg} / \mathrm{day} \text { (trough } 150- \\
200 \mathrm{ng} / \mathrm{mL} \text { ) for } 49.5 \text { weeks }\end{array}$ & $41 \%$ relapse rate & $\begin{array}{l}\text { Data not } \\
\text { available }\end{array}$ \\
\hline Maas et al. [29] & $\begin{array}{l}\text { Retrospective cohort study. Seven patients } \\
\text { with CsA as } 2 \text { nd line agent in combination } \\
\text { with GC }\end{array}$ & $\begin{array}{l}300(150-400) \mathrm{mg} / \text { day for } \\
131 \text { weeks }\end{array}$ & $86 \%$ relapse rate & $\begin{array}{l}\text { Data not } \\
\text { available }\end{array}$ \\
\hline Ponticelli et al. [60] & $\begin{array}{l}\text { Open-label RCT in } 73 \text { patients with SD or FR } \\
\text { MCD (CYC vs. CsA) }\end{array}$ & $\begin{array}{l}5 \mathrm{mg} / \mathrm{kg} / \text { day for } 9 \text { months } \\
\text { (trough } 200-600 \mathrm{ng} / \mathrm{mL} \text { ) }\end{array}$ & $\begin{array}{l}86 \% \text { relapse rate in } \mathrm{FR} \text { and } \\
57 \% \text { relapse rate in SD patients } \\
75 \% \text { relapse rate in all patients at } \\
24 \text { months ( } 50 \% \text { adults and } 80 \% \\
\text { children) }\end{array}$ & $\begin{array}{l}\text { Data not } \\
\text { available }\end{array}$ \\
\hline Eguchi et al. [62] & $\begin{array}{l}\text { Prospective open-label RCT in patients with } \\
\text { relapsing MCD. Patients randomized to CsA } \\
+ \text { PSL group }(n=26) \text { vs. the PSL alone }(n= \\
\text { 26) }\end{array}$ & $\begin{array}{l}\text { CsA (AUC } 1,700-2,000 \mathrm{ng} / \\
\mathrm{mL})+ \text { PSL }(0.8 \mathrm{mg} / \mathrm{kg} / \mathrm{day}) \\
\text { group vs. PSL alone ( } 1 \mathrm{mg} / \\
\mathrm{kg} / \text { day })\end{array}$ & $\begin{array}{l}19 \% \text { relapse rate }(\mathrm{Cs} A+\mathrm{PSL}) \text { and } \\
23 \% \text { relapse rate }(\mathrm{PSL} \text { only) at } 6 \\
\text { months }\end{array}$ & $\begin{array}{l}\text { Data not } \\
\text { available }\end{array}$ \\
\hline \multicolumn{5}{|l|}{$T A C$} \\
\hline Fenton et al. [28] & $\begin{array}{l}\text { Retrospective observational cohort. Fifteen } \\
\text { patients were treated with CsA and } 10 \\
\text { patients treated with TAC as } 2 \text { nd line agent } \\
\text { for } 18 \text { months. Three patients had SR and } 22 \\
\text { patients had FR MCD }\end{array}$ & Data not available & $64 \%$ relapse rate & $\begin{array}{l}\text { Median time to } \\
\text { relapse: } 7 \\
\text { months }(2-22)\end{array}$ \\
\hline
\end{tabular}




\begin{tabular}{|c|c|c|c|c|}
\hline Medication & Evidence & Regimen & Relapse rate & Time to relapse \\
\hline \multicolumn{5}{|l|}{ Mycophenolate mofetil } \\
\hline Pesavento et al. [63] & $\begin{array}{l}\text { Four adults with FR MCD after failing CYC } \\
\text { therapy }\end{array}$ & $\begin{array}{l}\text { MMF } 1,000-1,500 \mathrm{mg} \\
\text { daily in divided doses for } \\
19-42 \text { months }\end{array}$ & $25 \%$ relapse rate & $\begin{array}{l}\text { Data not } \\
\text { available }\end{array}$ \\
\hline \multicolumn{5}{|l|}{ RTX } \\
\hline Fenton et al. [28] & $\begin{array}{l}\text { Retrospective observational cohort. Four } \\
\text { patients treated with RTX as 2nd line agent }\end{array}$ & Data not available & No relapse at last follow-up & \\
\hline $\begin{array}{l}\text { Munyentwali et al. } \\
\text { [67] }\end{array}$ & $\begin{array}{l}\text { Case series in } 17 \text { adults with FR and SD MCD } \\
\text { unresponsive to several immunosuppressive } \\
\text { agents }\end{array}$ & $375 \mathrm{mg} / \mathrm{m}^{2} 1-4$ infusions & $\begin{array}{l}35 \% \text { relapse rate } \\
6 / 17 \text { patients relapsed and } \\
\text { remission was reinduced with } \\
\text { GC and they again received RTX } \\
\text { as GC sparing agent }\end{array}$ & $\begin{array}{l}\text { Mean time to } \\
\text { relapse: } 11 \\
\text { months }(4.8- \\
16.3 \text { months })\end{array}$ \\
\hline Ruggenenti et al. [69] & $\begin{array}{l}\text { Longitudinal, off-on study in } 20 \text { adult patients } \\
\text { with steroid-dependent or FR NS and } 10 \\
\text { children (MCD or FSGS). Patients were in } \\
\text { GC-induced remission at the time of RTX } \\
\text { administration }\end{array}$ & $\begin{array}{l}1-2 \text { doses of RTX }(375 \mathrm{mg} / \\
\left.\mathrm{m}^{2}\right) \text { with tapering of other } \\
\text { immunosuppression } \\
\text { At } 1 \text { year, all patients were } \\
\text { in remission: } 18 \text { were } \\
\text { treatment-free and } 15 \\
\text { never relapsed }\end{array}$ & $\begin{array}{l}\text { Relapse rate: } 40 \% \text { (adults), } \\
70 \% \text { (children), } \\
55 \% \text { (MCD/MesGN), 38\% (FSGS) }\end{array}$ & $\begin{array}{l}\text { Median time to } \\
\text { relapse after } \\
\text { RTX therapy } \\
7.5 \text { months } \\
(0.5-10.7)\end{array}$ \\
\hline
\end{tabular}

MCD, minimal change disease; NS, nephrotic syndrome; GC, glucocorticoid; CsA, cyclosporine; TAC, tacrolimus; RTX, rituximab; CR, complete remission; CYC, cyclophosphamide.

low-up relapse rates were similar between the two groups (63.6 vs. $70 \%, p=\mathrm{NS}$ ).

Matsumoto et al. [55] studied 3 different regimens to treat 26 de novo and 10 relapsed Japanese adult MCD patients in a prospective study. Patients were 35 years old with a UPCR of $6.1 \mathrm{~g} /$ day and serum albumin of $2.3 \mathrm{~g} / \mathrm{dL}$.
Twelve patients were given CsA alone (dose $2-3 \mathrm{mg} / \mathrm{kg} /$ day, trough $\leq 150 \mathrm{ng} / \mathrm{mL}$ ), and 12 patients received CsA after intravenous pulse methylprednisolone therapy $1,000 \mathrm{mg}$ daily for 3 days (CsA/PMT group). The initial CsA dose was continued for 12 months, then tapered by 25 mg every 2 months. The other 12 patients were given 
oral prednisolone (PSL, 40-60 mg/day) alone for 4-6 weeks, followed by daily PSL, with slowly tapering doses. CR was obtained in $75 \%$ with CsA alone, $100 \%$ with CsA/ PMT and $92 \%$ with PSL alone $(p=0.0379)$. The median time to remission was shortest in the CsA/PMT group $(11.0 \pm 5.6$ days with CsA/PMT vs. $21.5 \pm 15.8$ with PSL alone vs. $40.9 \pm 35.5$ days with CsA). CsA-associated adverse effects were minimal, but more patients in the PSL group had serious adverse effects or cushingoid features.

In general, tacrolimus has a more favorable side effect profile than CsA, and with more familiarity in kidney transplantation, tacrolimus is increasingly preferred for steroid-sparing therapies in MCD. CsA may be preferred in those at high risk for diabetes.

\section{Rituximab Monotherapy}

There is interest but limited data on the use of rituximab monotherapy for induction in MCD. In addition to depleting CD20 B cells, rituximab binds directly to podocyte SMPDL3b, leading to direct antiproteinuric effects [13]. Depletion of antigen-presenting B cells by rituximab may restore the balance between autoreactive $\mathrm{T}$ cells and regulatory $T$ cells [56] and suppress interleukin-13 secretion by Th2 cells [57]. A role in the suppression of potential autoreactive antibodies is also being investigated in MCD. Fenoglio et al. [58] published a case series of 6 adults ( 2 male and 4 female, mean age 62.7 years) with de novo MCD who treated with rituximab $\left(375 \mathrm{mg} / \mathrm{m}^{2}\right.$ times 4 weekly doses) as they had contraindications to steroid therapy. Five of 6 patients (83\%) achieved CR and 1 patient had a $75 \%$ reduction in proteinuria, although the responses were delayed in 2 patients ( $>3-6$ months). None of the patients relapsed during follow-up of 8-36 months.

\section{Steroid Minimization Approaches: Treatment of Relapsing Disease}

Therapies to prevent relapses and avoid recurrent courses of GC in adults include cyclophosphamide, calcineurin inhibitors, mycophenolate mofetil, and rituximab (Table 5). Levamisole has been used in the pediatric population, but there is a paucity of literature regarding this drug in adults. Typically, these drugs are given after remission has been induced with GC. Patients often continue low-dose GC concurrently with these agents, and the dose of GC is then tapered over time and discontinued. Cyclophosphamide (commonly $2-2.5 \mathrm{mg} / \mathrm{kg} / \mathrm{day}$ for 12 weeks) has been studied in observational studies in relapsing disease with a prolonged remission rate of up to $80 \%$ in steroid-dependent and frequently relapsing patients [26, 28-30,59-61]. Patients must be counseled regarding the risks of infectious, hematologic, gonadal toxicity, malignancy risk, and repeated doses should be avoided to prevent cumulative toxicity [35]. Calcineurin inhibitors are effective agents to induce remission, and also as maintenance agents to prevent relapses, but are associated with high relapse rates upon discontinuation ( 40\%) [26, 28, 29, 60-62]. Mycophenolate mofetil has also been used to prevent relapses [28, 63, 64].

More recently, rituximab has been shown to be effective in the prevention of relapses in both children $[65,66]$ and adults [28, 67-69]. Rituximab is now the standard of care in the pediatric population with steroid-dependent MCD based on the results of these 2 randomized controlled trials. Ravani et al. [65] conducted an open-label, noninferiority RCT in Italian children with steroid-dependent NS. Subjects were randomized to continue prednisone alone $(n=15)$ for 1 month or to add a single intravenous infusion of rituximab $\left(375 \mathrm{mg} / \mathrm{m}^{2}, n=15\right)$. Prednisone was tapered in both groups after 1 month. The primary outcome of proteinuria at 3 months was $42 \%$ lower in the rituximab group ( $28 \mathrm{vs} .49 \mathrm{mg} / \mathrm{m}^{2} /$ day) which met the noninferiority criteria. The mean prednisone dose at 3 months was lower in the rituximab group than in the control group $(0.09 \pm 0.21$ vs. $0.54 \pm 0.39 \mathrm{mg} / \mathrm{kg}$ per day). Fourteen of 15 children in the control group relapsed during tapering of the prednisone dose, whereas only 1 child in the rituximab group relapsed within 6 months of randomization. At 1 year, $66 \%$ of the children assigned to rituximab were still in steroid-free remission and the median relapse-free time following each infusion was 18 months. Steroid withdrawal was not possible in the control group, and all children required a steroidsparing agent within a month of attempting the steroid taper. Iijima et al. [66] randomized Japanese children with frequently relapsing or steroid-dependent NS to either rituximab $(n=24)$ at $375 \mathrm{mg} / \mathrm{m}^{2}$ weekly for 4 doses or placebo $(n=24)$. Children receiving prednisolone for the relapse of NS at screening continued receiving the drug for 4 weeks, and the dose was then tapered. Patients were followed up for 1 year. The primary endpoint of relapse-free period was $73 \%$ longer in the rituximab group compared to the placebo group (267 vs. 101 days, HR $0.27, p<0.0001)$. The time to treatment failure was longer in the rituximab group than in the placebo group (HR $0.27, p=0.0005$ ) and the mean GC dose after randomization was significantly lower in the rituximab group (8.37 vs. $20.02 \mathrm{mg} / \mathrm{m}^{2}$ per day, $\left.p<0.0001\right)$. Serious adverse 
events were not significantly different ( 42 vs. $25 \%, p=$ $0.36)$.

In adults, Munyentwali et al. [67] reported a series of frequently relapsing or steroid-dependent adults $(n=17$; ages 18-65 years; 13 males, 4 females) with MCD treated with rituximab. All the subjects had failed prior immunosuppressive therapy with different agents and had experienced an average of about 1.3 relapses per year before rituximab therapy. Two-thirds of the patients treated with rituximab had prolonged relapse-free remissions (66\%) during an average follow-up of 27 months, and $82 \%$ of the patients were able to discontinue other immunosuppressive agents. No significant adverse events were observed. Ruggenenti et al. [69] described 20 adult patients with steroid-dependent or frequently relapsing NS (MCD or focal segmental glomerulosclerosis) who received a single dose of rituximab $\left(375 \mathrm{mg} / \mathrm{m}^{2}\right)$ with tapering of other immunosuppression. Sixty percent of patients remained relapse-free, and were able to discontinue GC maintenance therapy. These data are encouraging and rituximab is now widely used to prevent MCD relapses in adults. The exact dosing regimen remains unclear, with some choosing a single dose of rituximab 375 $\mathrm{mg} / \mathrm{m}^{2}$, repeating after 1 week if $B$ cell depletion is not achieved (CD19 count $<5$ cells $/ \mathrm{mm}^{3}$ ), whereas others choose doses similar to those used in other glomerular diseases $\left(375 \mathrm{mg} / \mathrm{m}^{2}\right.$, weekly times 4 doses, or 1,000 mg twice, 2 weeks apart).

\section{Conclusion}

MCD in adults is typically a steroid-sensitive lesion; however, high doses are needed, therapy is often prolonged, and relapses are frequent. High cumulative exposure to GC may lead to a myriad of adverse effects. Careful dosing and prophylactic therapies may mitigate some of these risks, but minimizing exposure to GC is a goal for both physicians and patients. Fortunately, new data over the last few years show some promising options for minimizing or even avoiding GC, while still maintaining efficacy in the treatment of this disorder. As basic science further progresses our understanding of the pathophysiology and specific pathways underlying MCD, we can expect more targeted therapies in the future, with the promise of even fewer adverse events.

\section{Conflict of Interest Statement}

The authors have no conflicts of interest to declare.

\section{Funding Sources}

No research funding relevant to this article.

\section{Author Contributions}

Drs. Koirala and Jefferson both wrote this review.

\section{References}

1 Haas M, Meehan SM, Karrison TG, Spargo $\mathrm{BH}$. Changing etiologies of unexplained adult nephrotic syndrome: a comparison of renal biopsy findings from 1976-1979 and 19951997. Am J Kidney Dis. 1997;30:621-31.

2 Cameron JS. Nephrotic syndrome in the elderly. Semin Nephrol. 1996 Jul;16(4):319-29.

3 Gesualdo L, Di Palma AM, Morrone LF, Strippoli GF, Schena FP. The Italian experience of the national registry of renal biopsies. Kidney Int. 2004;66:890-4.

4 Walsh M, Merkel PA, Peh CA, Szpirt W, Guillevin L, Pusey CD, et al. Plasma exchange and glucocorticoid dosing in the treatment of antineutrophil cytoplasm antibody associated vasculitis (PEXIVAS): protocol for a randomized controlled trial. Trials. 2013 Mar 14;14:73.

5 Rovin BH, Solomons N, Pendergraft WF 3rd, Dooley MA, Tumlin J, Romero-Diaz J, et al. A randomized, controlled double-blind study comparing the efficacy and safety of dose-ranging voclosporin with placebo in achieving remission in patients with active lupus nephritis. Kidney Int. 2019 Jan;95(1): 219-31.
6 Jayne DRW, Bruchfeld AN, Harper L, Schaier M, Venning MC, Hamilton P, et al. Randomized trial of $\mathrm{C} 5 \mathrm{a}$ receptor inhibitor avacopan in ANCA-associated vasculitis. J Am Soc Nephrol. 2017 Sep;28(9):2756-67.

7 Chávez-Mendoza CA, Niño-Cruz JA, CorreaRotter R, Uribe-Uribe NO, Mejía-Vilet JM. Calcineurin inhibitors with reduced-dose steroids as first-line therapy for focal segmental glomerulosclerosis. Kidney Int Rep. 2019 Jan;4(1):40-7.

8 Ozeki T, Katsuno T, Hayashi H, Kato S, Yasuda Y, Ando M, et al. Short-term steroid regimen for adult steroid-sensitive minimal change disease. Am J Nephrol. 2019;49(1):54-63.

9 Saleem MA, Kobayashi Y. Cell biology and genetics of minimal change disease. F1000Res. 2016 Mar 30;5.

10 Araya C, Diaz L, Wasserfall C, Atkinson M, $\mathrm{Mu} \mathrm{W}$, Johnson R, et al. T regulatory cell function in idiopathic minimal lesion nephrotic syndrome. Pediatr Nephrol. 2009;24:1691-8.

11 Garin EH, Diaz LN, Mu W, Wasserfall C, Araya C, Segal M, et al. Urinary CD80 excretion increases in idiopathic minimal-change disease. J Am Soc Nephrol. 2009;20(2):260-6.
12 Lai KW, Wei CL, Tan LK, Tan PH, Chiang GS, Lee CG, et al. Overexpression of interleukin-13 induces minimal-change-like nephropathy in rats. J Am Soc Nephrol. 2007; 18(5):1476-85.

13 Fornoni A, Sageshima J, Wei C, MerscherGomez S, Aguillon-Prada R, Jauregui AN, et al. Rituximab targets podocytes in recurrent focal segmental glomerulosclerosis. Sci Trans] Med. 2011 Jun 1;3(85):85ra46.

14 Elie V, Fakhoury M, Deschênes G, Jacqz-Aigrain E. Physiopathology of idiopathic nephrotic syndrome: lessons from glucocorticoids and epigenetic perspectives. Pediatric Nephrology. 2012;27:1249-56.

15 Wernerson A, Dunér F, Pettersson E, Widholm SM, Berg U, Ruotsalainen V, et al. Altered ultrastructural distribution of nephrin in minimal change nephrotic syndrome. Nephrol Dial Transplant. 2003 Jan;18(1):70-6.

16 Topham PS, Kawachi H, Haydar SA, Chugh $\mathrm{S}$, Addona TA, Charron KB, et al. Nephritogenic mAb 5-1-6 is directed at the extracellular domain of rat nephrin. J Clin Invest. 1999; 104(11):1559-66. 
17 Watts AJB, Keller KH, Lerner G, Rosales I, Collins AB, Sekulic M, et al. Autoantibodies against nephrin elucidate a novel autoimmune phenomenon in proteinuric kidney disease. medRxiv. 2021.https://www.medrxiv.org/content/10.1101/2021.02.26.2125156 9v1.abstract.

18 Kadmiel M, Cidlowski JA. Glucocorticoid receptor signaling in health and disease. Trends Pharmacol Sci. 2013 Sep;34(9):518-30.

19 Ponticelli C, Locatelli F. Glucocorticoids in the treatment of glomerular diseases. Clin J Am Soc Nephrol. 2018;13(5):815-22.

20 Guess A, Agrawal S, Wei CC, Ransom RF, Benndorf R, Smoyer WE. Dose- and time-dependent glucocorticoid receptor signaling in podocytes. Am J Physiol Renal Physiol. 2010; 299(4):F845-53.

21 Ohashi T, Uchida K, Uchida S, Sasaki S, Nitta $\mathrm{K}$. Dexamethasone increases the phosphorylation of nephrin in cultured podocytes. Clin Exp Nephrol. 2011 Oct;15(5):688-93.

22 Zhang J, Pippin JW, Krofft RD, Naito S, Liu $\mathrm{ZH}$, Shankland SJ. Podocyte repopulation by renal progenitor cells following glucocorticoids treatment in experimental FSGS. Am J Physiol Renal Physiol. 2013 Jun 1;304(11): F1375-89.

23 Lewko B, Waszkiewicz A, Maryn A, Gołos M, Latawiec E, Daca A, et al. Dexamethasonedependent modulation of cyclic GMP synthesis in podocytes. Mol Cell Biochem. $2015 \mathrm{Nov}$; 409(1-2):243-53.

24 Black DA, Rose G, Brewer DB. Controlled trial of prednisone in adult patients with the nephrotic syndrome. Br Med J. 1970 Aug 22; 3(5720):421-6.

25 Korbet SM, Schwartz MM, Lewis EJ. Minimal-change glomerulopathy of adulthood. Am J Nephrol. 1988;8(4):291-7.

26 Waldman M, Crew RJ, Valeri A, Busch J, Stokes B, Markowitz G, et al. Adult minimalchange disease: clinical characteristics, treatment, and outcomes. Clin J Am Soc Nephrol. 2007 May;2(3):445-53.

27 Szeto CC, Lai FM, Chow KM, Kwan BC, Kwong VW, Leung CB, et al. Long-term outcome of biopsy-proven minimal change nephropathy in Chinese adults. Am J Kidney Dis. 2015 May;65(5):710-8.

28 Fenton A, Smith SW, Hewins P. Adult minimal-change disease: observational data from a UK centre on patient characteristics, therapies, and outcomes. BMC Nephrol. 2018 Aug 16;19(1):207.

29 Maas RJ, Deegens JK, Beukhof JR, Reichert LJ, ten Dam MA, Beutler JJ, et al. The clinical course of minimal change nephrotic syndrome with onset in adulthood or late adolescence: a case series. Am J Kidney Dis. 2017;69: $637-46$.

30 Nolasco F, Cameron JS, Heywood EF, Hicks J, Ogg C, Williams DG. Adult-onset minimal change nephrotic syndrome: a long-term follow-up. Kidney Int. 1986 Jun;29(6):1215-23.

31 Charlier C, Henegar C, Launay O, Pagnoux C, Berezné A, Bienvenu B, et al. Risk factors for major infections in Wegener granulomatosis: analysis of 113 patients. Ann Rheum Dis. 2009 May;68(5):658-63.

32 McGregor JG, Hogan SL, Hu Y, Jennette CE, Falk RJ, Nachman PH. Glucocorticoids and relapse and infection rates in anti-neutrophil cytoplasmic antibody disease. Clin J Am Soc Nephrol. 2012 Feb;7(2):240-7.

33 Goupil R, Brachemi S, Nadeau-Fredette AC, Déziel C, Troyanov Y, Lavergne V, et al. Lymphopenia and treatment-related infectious complications in ANCA-associated vasculitis. Clin J Am Soc Nephrol. 2013 Mar;8(3): 416-23.

34 Robson J, Doll H, Suppiah R, Flossmann O, Harper L, Höglund P, et al. Glucocorticoid treatment and damage in the anti-neutrophil cytoplasm antibody-associated vasculitides: long-term data from the European Vasculitis Study Group trials. Rheumatology. 2015 Mar; 54(3):471-81.

35 Jefferson JA. Complications of immunosuppression in glomerular disease. Clin J Am Soc Nephrol. 2018 Aug 7;13(8):1264-75.

36 Kyrieleis HA, Löwik MM, Pronk I, Cruysberg HR, Kremer JA, Oyen WJ, et al. Long-term outcome of biopsy-proven, frequently relapsing minimal-change nephrotic syndrome in children. Clin J Am Soc Nephrol. 2009 Oct; 4(10):1593-600.

37 Huscher D, Thiele K, Gromnica-Ihle E, Hein G, Demary W, Dreher R, et al. Dose-related patterns of glucocorticoid-induced side effects. Ann Rheum Dis. 2009 Jul;68(7):111924.

38 Hoes JN, Jacobs JW, Verstappen SM, Bijlsma JW, Van der Heijden GJ. Adverse events of low- to medium-dose oral glucocorticoids in inflammatory diseases: a meta-analysis. Ann Rheum Dis. 2009 Dec;68(12):1833-8.

39 Da Silva JA, Jacobs JW, Kirwan JR, Boers M, Saag KG, Inês LB, et al. Safety of low dose glucocorticoid treatment in rheumatoid arthritis: published evidence and prospective trial data. Ann Rheum Dis. 2006 Mar;65(3):28593.

40 Schäcke H, Döcke WD, Asadullah K. Mechanisms involved in the side effects of glucocorticoids. Pharmacol Ther. 2002 Oct;96(1):2343.

41 Ogi M, Yokoyama H, Tomosugi N, Hisada Y, Ohta S, Takaeda M, et al. Risk factors for infection and immunoglobulin replacement therapy in adult nephrotic syndrome. Am J Kidney Dis. 1994 Sep;24(3):427-36.

42 Glenn DA, Henderson CD, O'Shaughnessy $\mathrm{M}, \mathrm{Hu} \mathrm{Y}$, Bomback A, Gibson K, et al. Infection-related acute care events among patients with glomerular disease. Clin J Am Soc Nephrol. 2020 Dec 7;15(12):1749-61.

43 Hegarty J, Mughal MZ, Adams J, Webb NJ. Reduced bone mineral density in adults treated with high-dose corticosteroids for childhood nephrotic syndrome. Kidney Int. 2005 Nov;68(5):2304-9.

44 Vaccination of adults with renal disease [Internet]. 2020 [cited 2020 Nov 26]. Available from: https://www.cdc.gov/vaccines/adults/ rec-vac/health-conditions/renal-disease. html.

45 Park JW, Curtis JR, Moon J, Song YW, Kim S, Lee EB. Prophylactic effect of trimethoprimsulfamethoxazole for pneumocystis pneumonia in patients with rheumatic diseases exposed to prolonged high-dose glucocorticoids. Ann Rheum Dis. 2018;77(5):644-9.

46 Chew LC, Maceda-Galang LM, Tan YK, Chakraborty B, Thumboo J. Pneumocystis jirovecii pneumonia in patients with autoimmune disease on high-dose glucocorticoid. J Clin Rheumatol. 2015 Mar;21(2):72-5.

47 Teeninga N, Kist-van Holthe JE, van Rijswijk N, de Mos NI, Hop WC, Wetzels JF, et al. Extending prednisolone treatment does not reduce relapses in childhood nephrotic syndrome. J Am Soc Nephrol. 2013 Jan;24(1): 149-59.

48 Sinha A, Saha A, Kumar M, Sharma S, Afzal $\mathrm{K}$, Mehta A, et al. Extending initial prednisolone treatment in a randomized control trial from 3 to 6 months did not significantly influence the course of illness in children with steroid-sensitive nephrotic syndrome. Kidney Int. 2015;87(1):217-24.

49 Yoshikawa N, Nakanishi K, Sako M, Oba MS Mori R, Ota E, et al. A multicenter randomized trial indicates initial prednisolone treatment for childhood nephrotic syndrome for two months is not inferior to six-month treatment. Kidney Int. 2015 Jan;87(1):225-32.

50 Medjeral-Thomas NR, Lawrence C, Condon M, Sood B, Warwicker P, Brown H, et al. Randomized, controlled trial of tacrolimus and prednisolone monotherapy for adults with de novo minimal change disease: a multicenter, randomized, controlled trial. Clin J Am Soc Nephrol. 2020;15(2):209-18.

51 Rémy P, Audard V, Natella PA, Pelle G, Dussol B, Leray-Moragues $\mathrm{H}$, et al. An open-label randomized controlled trial of low-dose corticosteroid plus enteric-coated mycophenolate sodium versus standard corticosteroid treatment for minimal change nephrotic syndrome in adults (MSN Study). Kidney Int. 2018;94:1217-26.

52 Li X, Liu Z, Wang L, Wang R, Ding G, Shi W, et al. Tacrolimus monotherapy after intravenous methylprednisolone in adults with minimal change nephrotic syndrome. J Am Soc Nephrol. 2017 Apr;28(4):1286-95.

53 Chin HJ, Chae D-W, Kim YC, An WS, Ihm C, Jin D-C, et al. Comparison of the efficacy and safety of tacrolimus and low-dose corticosteroid with high-dose corticosteroid for minimal change nephrotic syndrome in adults. Am Soc Nephrol. 2020. ASN.2019050546.

54 Shirai S, Imai N, Sueki S, Matsui K, Tominaga $\mathrm{N}$, Sakurada T, et al. Combined cyclosporine and prednisolone therapy using cyclosporine blood concentration monitoring for adult patients with new-onset minimal change nephrotic syndrome: a single-center pilot randomized trial. Clin Exp Nephrol. 2018;22: 283-90. 
55 Matsumoto H, Nakao T, Okada T, Nagaoka Y, Takeguchi F, Tomaru R, et al. Favorable outcome of low-dose cyclosporine after pulse methylprednisolone in Japanese adult minimal-change nephrotic syndrome. Intern Med. 2004 Aug;43(8):668-73.

56 Datta SK. Anti-CD20 antibody is an efficient therapeutic tool for the selective removal of autoreactive T cells. Nat Clin Pract Rheumatol. 2009 Feb;5(2):80-2.

57 Kim JE, Park SJ, Ha TS, Shin JI. Effect of rituximab in MCNS: a role for IL-13 suppression? Nat Rev Nephrol. 2013;9(9):551.

58 Fenoglio R, Sciascia S, Beltrame G, Mesiano P, Ferro M, Quattrocchio G, et al. Rituximab as a front-line therapy for adult-onset minimal change disease with nephrotic syndrome. Oncotarget. 2018 Jun 22;9(48):28799-804.

59 Mak SK, Short CD, Mallick NP. Long-term outcome of adult-onset minimal-change nephropathy. Nephrol Dial Transplant. 1996 Nov;11(11):2192-201.
60 Ponticelli C, Edefonti A, Ghio L, Rizzoni G, Rinaldi S, Gusmano R, et al. Cyclosporin versus cyclophosphamide for patients with steroid-dependent and frequently relapsing idiopathic nephrotic syndrome: a multicentre randomized controlled trial. Nephrol Dial Transplant. 1993;8(12):1326-32.

61 Li X, Li H, Chen J, He Q, Lv R, Lin W, et al. Tacrolimus as a steroid-sparing agent for adults with steroid-dependent minimal change nephrotic syndrome. Nephrol Dial Transplant. 2008;23(6):1919-25.

62 Eguchi A, Takei T, Yoshida T, Tsuchiya K, Nitta K. Combined cyclosporine and prednisolone therapy in adult patients with the first relapse of minimal-change nephrotic syndrome. Nephrol Dial Transplant. 2010 Jan; 25(1):124-9.

63 Pesavento TE, Bay WH, Agarwal G, Hernandez RA Jr, Hebert LA. Mycophenolate therapy in frequently relapsing minimal change disease that has failed cyclophosphamide therapy. Am J Kidney Dis. 2004 Mar;43(3): e3-6.

64 Choi MJ, Eustace JA, Gimenez LF, Atta MG, Scheel PJ, Sothinathan R, et al. Mycophenolate mofetil treatment for primary glomerular diseases. Kidney Int. 2002;61(3):1098-114.
65 Ravani P, Rossi R, Bonanni A, Quinn RR, Sica $\mathrm{F}$, Bodria M, et al. Rituximab in children with steroid-dependent nephrotic syndrome: a multicenter, open-label, noninferiority, randomized controlled trial. J Am Soc Nephrol. 2015 Sep;26(9):2259-66.

66 Iijima K, Sako M, Nozu K, Mori R, Tuchida N, Kamei K, et al. Rituximab for childhoodonset, complicated, frequently relapsing nephrotic syndrome or steroid-dependent nephrotic syndrome: a multicentre, doubleblind, randomised, placebo-controlled trial. Lancet. 2014 Oct 4;384(9950):1273-81.

67 Munyentwali $\mathrm{H}$, Bouachi K, Audard V, Remy $\mathrm{P}$, Lang $\mathrm{P}$, Mojaat R, et al. Rituximab is an efficient and safe treatment in adults with steroid-dependent minimal change disease. Kidney Int. 2013 Mar;83(3):511-6.

68 Iwabuchi Y, Takei T, Moriyama T, Itabashi $\mathrm{M}$, Nitta K. Long-term prognosis of adult patients with steroid-dependent minimal change nephrotic syndrome following rituximab treatment. Medicine. 2014;93(29):e300.

69 Ruggenenti P, Ruggiero B, Cravedi P, Vivarelli $\mathrm{M}$, Massella L, Marasà $\mathrm{M}$, et al. Rituximab in steroid-dependent or frequently relapsing idiopathic nephrotic syndrome. J Am Soc Nephrol. 2014 Apr;25(4):850-63. 